\title{
土木学会論文報告集
}

第 327 号・1982 年 11 月

【論

文】

\section{道路交通システムの機能上の耐震性の一評価方法* \\ EVALUATION OF EARTHQUAKE PERFORMANCE \\ OF TRANSPORTATION SYSTEMS}

\author{
川上英 二** \\ By Hideji KAWAKAMI
}

\section{1. 序論}

活発な地震帯上にある本邦において地震㷋害を検討す る場合, 地震災害の程度に及ぼす交通システムの被害の 程度の影響は非常に大きい，交通システムの機能低下が 地震直後における消防車, 救急車, 災害復旧車などの緊 急車の活動を妨げ，火災などの二次災害を大きくさせる のみでなく, 地震後長期にわたって日常生活および産業 活動に支配的な影響を及ぼすことが過去の震害の例より 明らかである.これら交通システムの地震後における挙 動を分析し検討することは防災上重要であると考えられ る. その際，各交通施設の耐震性を seismicity，地盤条 件, 構造物の強度などにより評価するばかりでなく，機 能面からシステムの耐震性を検討する必要がある. さら に，逆に各交通施設を計画設計する際には，システムが 全体として所要の機能上の耐震性を保持するために十分 な強度を各施設に対し決定し, この結果に基づいて各施 設を耐震設計する必要がある.

従来, 耐震工学の分野で, 道路・橋梁・トンネルなど 各施設の耐震性の検討がされておりたと圭1)，一方，交通 工学の分野でおもに平常時における交通システムの機能 に関する研究が数多くなされているたとえ(゙2),3). また，近 年, 交通システムをライフラインという大きな範ちゅう でとらえ, おもに, 供給・需要地点間の連結性に着目 したシステムの機能上の耐震性の検討が行われてい る4 14). これらの基本的な研究に基づいて, さらに交 通システムの特質を考慮することにより, 地震後におけ る交通システムの機能上の耐震性を評価する方法を確立 することは重要であると考える. 一方, 最近, 交通シス テムの地震時に打ける安全性を検討した研究としてはい くつかの研究が報告されている(5),16)が，その多くは問

* 土木学会年次学術講演会 I 部, 1980 年で一部発表

** 正会員 工博 埼玉大学助手 工学部建設工学科
題点の指摘または定性的な解析方法を示すにとどまって 抢り, システムの機能上の耐震性が十分に評価されるた めの手法が展開されているとはいえない。また，高橋 $ら^{17)}$ は災害時における道路網の交通流をマルコフ過程と 仮定して解析を行っている. しかし，この研究はドライ バーが事前に通行不能の情報を全然もっていない場合に ついての交通流の解析方法を示したものであり, 地震の 発生の諸元と通行不能箇所との関係を考慮していないの みならず，システムを構成する各施設のシステム内にお ける 地震後の位置づけをたは役割を検討していないた め，各施設の耐震設計を行うに際して有用な情報を得る ためには不十分なものとなっている.

本論文では，交通システムとして道路交通システムを 取り上げ，まず，システムを構成する各施設の地震によ る破壊を評価するための確率論的なモデルを組み立て た. 次に，モンテカルロシミュレーションを用いて地震 後の連結性から調べたシステムの状態を検討するための 方法を展開し, さらに, 交通量配分の手法を用いてシス テムの機能の低下の程度を評価するための方法を，ま た, 地震後における各道路の役割を評価するための方法 を提案した. 最後に, 数值計算例として, 1978 年の伊 豆大島近海地震により実際に被害が生じた伊豆半島の道 路網に本手法を適用し, その有用性を検討した.

\section{2. 伊豆大島近海地震による道路施設の 破壊状況}

図一1 は数值計算の対象の一例とした伊豆半島の道路 交通システムであるたただし，本図では国道，主要地方 道, 道路公団の有料道路, 県道天城有料道路のみを示し てあるが，これらの道路は伊豆半島のいわば動脈的な交 通システムを形成しているものと考えられる. 図中 $\times$ 印 は 1978 年の伊豆大島近海地震によるこれら幹線道路の おもな破壊箇所の分布を, 静岡県の下田・熱海・沼津各 


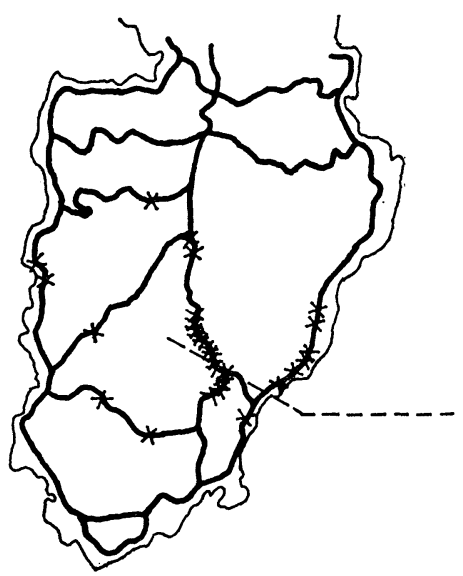

図一1 伊豆大島近海地震 (1978) による幹線道路の不通 箇所 (静岡県下田・熱海・沼津各土木事務所の資

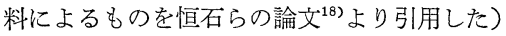

土木事務所の資料に基づいてまとめた恒石らの論文 ${ }^{18)}$ か ら引用して示したものである. ただし, 図中に示した被 害䈏所は地震後に一定期間全面通行止めとなった箇所で あり, 小規模の崩落, 路肩のゆるみなどで片側通行とな った箇所は含まれていない。これらの破壊は, 伊豆半島 の大部分が山地・丘陵地であるという自然条件を反映し て, 平野部の軟弱地盤に帰因するような被害は少なく, 稲取に出現した地震断層による被害を別にすると，大部 分が斜面崩壊によって生じたものである. 地震後数日に わたって交通路は至る所で遮断され，交通途絶地域（孤 立地域）が生じたばかりでなく, 道路交通システムが完 全に復旧されるのに地震後数か月を要している.

\section{3. 道路施設の破壊確率の推定}

地震による道路交通システムの機能低下の原因として は，斜面崩壊，橋・トンネルの破壊，道路の亀裂・段 差, 落下した看板・ビル外装材・横断歩道橋などの障害 物, 道路周辺の火災, 交通信号の破壊などを挙げること ができ，これらの破壊が発生する確率は概略以下のよう な手順で求めることができる.

(1) 地震発生の場所, 規模, およびその頻度について の seismicity に関する研究に基づいて, システムに被 害を及ぼす大規模地震の震源モデルを設定する.

(2) 地震の規模, 震央距離および地震動の強さの関係 を示す attenuation 式，および地盤条件と地震動の強さ との関係に関する研究に基づいて, 各地点における地震 動の強さを算定する.

(3) 斜面, 橋梁, トンネル, 道路面などの各施設構造 物に(2)で求められた強さの地震動が外力として作用した 場合に，これらの構造物が破壞する確率を，構造物の強
度, 特性などを考慮して算定する.この方法の一例とし

$\tau$, 斜面崩壊の発生確率の算定方法について以下に詳述 する.

地震による斜面崩壊の発生に関する研究は従来数多く 行われており, これらの研究は以下の 3 つの方法に大別 することができる.

(1) 地質学的な考察に基づき, 斜面崩壊の定性的な原 因を推定する方法

(2) すべり面を考慮して土圧論を用いて力学的に解析 する方法

(3) 過去の震害記録を数多く集め,これらを統計的に 解析する方法

伊豆大島近海地震（1978）により発生した斜面崩壞に 対しても以上の 3 つのそれぞれの方法により研究が行わ れている．たとえば恒石ら ${ }^{18)}$ は(1)方法を用いて，おの おのの斜面崩壊のおもな原因を，地表風化・熱水変質・ 断層破砝などの作用により斜面を構成する岩盤の強度が 低下していること，あるいは降下火山物質などの固結度 の小さい二次的堆積物が斜面を被覆していることなどで あると推定している.また，岩崎ら ${ }^{19}$ は(2)の力学的方法 に基づいて，有限要素法を用いて斜面の崩壊に対する安 全性を論じている.

一方, 田村 ${ }^{20)}$ は(3)の方法に基づき, 地震のマグニチュ 一ド, 震央距離掞よび斜面崩壊の発生籄所数（多発域, 散発域の 2 種類に分けて表示) の関係を，過去の多くの 震害記録を統計的に整理することにより求めている.こ の結果に，国井ら ${ }^{21)}$ は伊豆大島近海地震 (1978) の結果 を追加しデータの数を増加させている.また，これとは 別に, 道路 $1 \mathrm{~km}$ 当たりの被害箇所数と断層線 ${ }^{21}$ からの 距離との関係を詳細に求めている.

また，荏本ら ${ }^{22)}$ は(3)の統計解析的方法である数量化理 論を用いて道路の被害発生頻度と被害発生要因との関係 を論じている．ただし，被害発生頻度としては道路 1 $\mathrm{km}$ 当たりの被害䇢所数を用い, また, 被害発生要因と しては, 擁壁の構造, 高さ, 傾斜角, 複合構造の有無, 震源と斜面とのなす角度, 震源距離, 施工条件を用いて いる. そして, 単位距離当たりの被害箇所数の平均值 を斜面の各要因についての状態から推定する式を算出し ている.

以上の関係を用いれば，対象とするシステム内の細分 割されたすべての道路区画に対して，単位距離当たりの 斜面崩壊による 被害発生の平均箇所数 $\nu$ を推定するこ とが可能であり，ここでは各破壊が独立であるポアソン 過程であると仮定すると, 長さ $l$ の道路区画が安全であ る確率は

$$
P=\exp (-\nu l)
$$

で算定できる.さらに，都市 $i, j$ をつなぐ $k$ 個の直列 
な道路区画から構成される 1 本の道路が安全である確率 ${ }_{s} q_{i j}$ (以下サフィックス $s, f$ は survive, failure の頭 文字を表わす）は，各区画に対する $\nu_{1}, \cdots, \nu_{k}$ および $l_{1}, \cdots, l_{k}$ を用いて $P_{1}, \cdots, P_{k}$ を算定し，これらの積で 求められる。つまり,

$$
{ }_{s} q_{i j}=\prod_{l=1}^{k} P_{l}
$$

\section{4. 連結性を考慮した道路交通システムの 耐震性の評価}

前述したように地震直後に交通途絶地域（孤立地域） が生ずることは，緊急車の活動を妨げ二次苂害を大きく させる原因となる，地震直後においても，緊急車のため の交通路が確保され，また，病院・消防署などの緊急施 設が有効に機能するように配置されていることは災害を 最小限に食い止めるために重要なことであると考えられ る. 以上の観点に基づいて，まず，道路交通システムの 耐震性を評価するに際して，システムを単純に節点とリ ンクから構成されるネットワークシステムとモデル化し て取り扱うこととする．そして，連結性を評価の尺度と して採用することにした．地震後の連結，非連結は節点 ペア間によって異なるから，その耐震性は節点ペアそれ ぞれに対し確率で与えられることになるが，節点ペア間 に1つ以上の非破壞のパスが存在する場合，そのペアは 連結であると定義し，その確率——連結確率 $s_{i j}(i, j$ は 2 つの節点番号のペア)——耐震性を表わす值と考 えた ${ }^{8), 10)}$.

式（2）で示したようにすべてのリンクについて非破 壞確率 ${ }_{s} q_{i j}(i, j$ はリンクの両端の節点番号) が推定で き，また各リンクの破壊が互いに独立であるものとす る. 従来, 節点ペア間の連結確率 $s p_{i j}$ を求める方法と して, $\mathrm{SSSP}^{5,, 6)}$ ，ブール 代数 ${ }^{7) ， ま た は モ ン テ カ ル ロ ~}$ 法を利用した方法が提案されている．本論文では田村・ 川上 ${ }^{8), 10)}$ により提案されたモンテカルロ法を用いた方法 を用いて節点ペア間の連結確率を算定し，この性質を検 討した結果（(1) に示す）に基づいて，連結性から調べ たシステムの構造を視覚的に把握すること（(2) で展 開)を試みた。

\section{（1）非連結確率の性質}

以上で定義した節点ペア $i j$ の連結確率に対し，非連 結確率 ${ }_{f} P_{i j}$ を

$$
{ }_{f} p_{i j}=1-{ }_{s} p_{i j}
$$

で定義すると，この值は節点ペア $i j$ 間に非破壊である パスが 1 つも存在しない確率である.この非連結確率

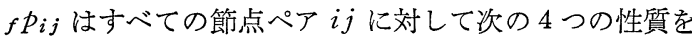

もっている．ただし，ここでは節点が破壊しないものと 仮定した.

$$
\begin{aligned}
& 0 \leqq{ }_{f} p_{i j} \\
& { }_{f} p_{i i}=0 \\
& { }_{f} p_{i j}={ }_{f} p_{j i} \\
& { }_{f} p_{i j} \leqq{ }_{f} p_{i k}+{ }_{f} p_{k j}
\end{aligned}
$$

式 (4) は $f_{i j}$ が確率であり， 0 と 1 との間の值であ ることより，また，式 (5) は節点 $i$ はそれ自身の節点 $i$ と非連結となることはないことより明らかであり，ま た，式 (6) は道路が一方通行とはならずネットワークが 無向であることを表わしている．最後の式 (7) の三角不 等式は次のように証明できる。

つまり，任意の 3 つの節点 $i, j, k$ のうち 2 つずつの ペア $(i, j),(i, k),(k, j)$ が 連結している場合の事象の集 合をそれぞれ集合 $H_{i j}, H_{i k}$, $H_{k j}$ で表わし，非連結であ る場合の事象の集合をその補 集合 $\bar{H}_{i j}, \bar{H}_{i k}, \bar{H}_{k j}$ で表わ すと図一2 に示すベン・ダイ アグラムが得られる、ところ が $(i, k),(k, j)$ がともに連

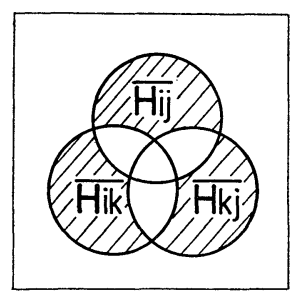

図一2 ベン・ダイア グラム 結の場合 $i \rightarrow k \rightarrow j$ のパスが存在し， $(i, j)$ は連結であ る.したがって，集合

$$
H_{i j k}=\bar{H}_{i j} \cap H_{i k} \cap H_{k j}
$$

は空集合となる．さらに，この関係は $i, j, k$ に対して サイクリックに成立し，図一2 の斜線部は空集合とな り, 次式が成立する.

$$
\bar{H}_{i j} \subset\left(\bar{H}_{i k} \cup \bar{H}_{k j}\right)
$$

したがって，式（7）が証明される. これら 4 つの性質 (式 (4) （7)）より非連結確率 ${ }_{f} p_{i j}$ 浪距離としての性 質をもっていることがわかる.

\section{（2） システムの構造の視覚化}

（1）で導いたように非連結確率 ${ }_{f} p_{i j}$ が距離としての 性質をもっていることを利用して，本節ではシステムを 構成する $n_{0}$ 個の節点を $n_{0}$ 次元ユークリッド空間に非 連結確率 $f_{p} p_{i j}$ を距離として配置することを考えた. む とより，式 (4)〜 (7) の距離としての条件だけから は，節点をすべての距離が峳密に満足されるようにユー クリッド空間に配置することができるとはいえない，し かし，システムの構造の概略を把握するためにはこの空 間を選ぶことが適当であると考えた.ささらにこのシス テムの構造を鮮明に視覚化するため多次元尺度構成法 ${ }^{23}$ を適用した. これは多数の集団の集団構造を理解するた めの手法であり，2つずつのものの関係（相違の度合あ るいは距離）を用いて，これらを空間配置して，この空 
川上：

間内のばらつきの最も大きい方向に座標軸を直角に順次 決めて, 少ない次元でデータの構造を把握する方法で ある.

$n_{0}$ 個の節点の重心を原点とした場合，原点から節点 $j$ または $k$ に至る 2 つのベクトルの内積は節点間の距 離 $f_{f} p_{i j}$ を用いて次式のように

$$
\begin{aligned}
b_{j k}{ }^{*}= & \frac{1}{2}\left[\frac{1}{n_{0}} \sum_{j=1}^{n_{0}} f p_{j k}{ }^{2}+\frac{1}{n_{0}} \sum_{k=1}^{n_{0}} f p_{j k}{ }^{2}-f_{j k}{ }^{2}\right. \\
& \left.-\frac{1}{n_{0}{ }^{2}} \sum_{j=1}^{n_{0}} \sum_{k=1}^{n_{0}} f p_{j k}{ }^{2}\right] \ldots \ldots \ldots \ldots \ldots \ldots(10)
\end{aligned}
$$

表わされる. ところが, 上述の原点にもう 1 つの $m$ 次 元の直交座標系を考光, 節点 $j$ の座標を $\left\{x_{j_{1}}, x_{j_{2}}, \cdots\right.$, $\left.x_{j \alpha}, \cdots, x_{j m}\right\}$ で表わせば $b_{j k}{ }^{*}$ は内積であるから

$$
b_{j k} * \approx \sum_{\alpha=1}^{m} x_{j \alpha} x_{k \alpha}
$$

と近似できる.したがって，ばらつきの最も大きい方向 に座標軸を直角に順次定めた場合の節点 $j$ の第 $\alpha$ 番目 の座標軸に対する座標 $x_{j \alpha}$ 㳄次式で求められる.

$$
x_{j \alpha}=\sqrt{\lambda_{\alpha}} z_{j \alpha}
$$

ただし, $\lambda_{1} \geqq \cdots \geqq \lambda_{\alpha} \geqq \cdots \geqq \lambda_{m} \geqq \cdots \geqq \lambda_{n_{0}} \geqq 0$ を行列 $\left[b_{j k}{ }^{*}\right]$ の固有值とし, $\left\{z_{1 \alpha}, \cdots, z_{n_{0} \alpha}\right\}$ を固有值 $\lambda_{\alpha}$ に対 する基準化された固有べクトルとする. この場合, $m$ 次 元までで表わされる分散の割合（累積分散率）rは次式 で求められる.

$$
r=\sum_{\alpha=1}^{m} \lambda_{\alpha} / \sum_{\alpha=1}^{n_{0}} \lambda_{\alpha} .
$$

\section{（1） 機能低下の評価方法}

本評価方法は, 大別して

(1) 平常時の道路交通流の解析

(2) 地震による道路施設の破壊確率の推定

(3) 地震後の交通流のシミュレーション

(4) 交通システムの耐震性の評価

の 4 つの手順から構成されている (図一3 参照).

(1) 平常時の道路交通流の解析は, 各ゾーンの発生交 通量・吸引量から OD 分布交通量を推定し，道路網を 考慮して交通流を解析する方法であり, 従来, 交通工学 の分野で提案されている方法を用いる.

(2) 地震による道路施設の破壊確率の推定にあたって は，3．に示したように seismicity，地盤条件，構造物 の強度などを考慮して算定する．その場合，各施設の破 壊確率を破壊程度の関数として求めておく必要がある.

(3) (2)で求めた破壊確率を用いて各道路施設の破壊の シミュレーションを行う.ここでは，これらの破壊によ り各道路の交通容量が減少するものと仮定し, 各道路の 地震後の交通容量を推定する. 一方, 交通需要について 考えると, この量も地震後には平常時と比較して大きく 変化するものと考えられる，地震が及ぼす社会的・経済 的影響により，また各トリップの目的によりこの変化の 程度は大きく異なるものと考えられる.ささらには，この 交通需要量はこれから求めようとしている地震後の交通

\section{5. 交通容量を考慮したシステムの 機能低下の評価}

前章で展開した方法は連結性のみに着目した, おもに地震直後における交通途絶地域（孤立地 域）を対象とした解析であり，緊急車のための交 通路の耐震強度, およびシステムの形状の決定, または緊急施設の配置を決定する際に役立つもの と考えられる. これに対し，これらシステムの破 壊が地震後長期間にわたって日常生活, 産業活動 に与える影響を考える場合，システムの復旧期間 中の機能低下の状態を交通容量をも考慮して予測 しておく必要があると考える.また，さらには， システムの機能の耐震性の観点から調べた各道路 の役割を明確にし，この結果を各道路の耐震設計 強度の程度に反映させておくことが望ましいと考 える. 以上の観点から本章の（1）では容量をも 考慮した解析方法について概説し，(2) では簡単 な例を用いてシステムの機能の耐震性の観点から 調べた各道路の役割の評価方法について検討し た.

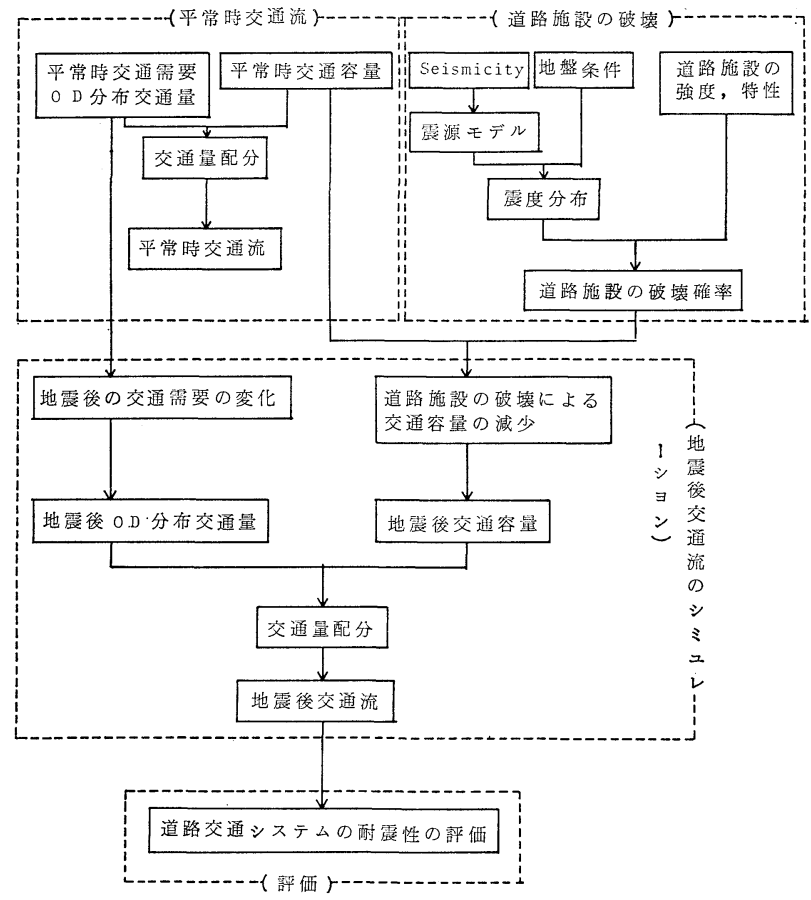

図一3 道路交通システムの耐震性の評価方法 
流の状態により影響を受けるものと推察される. しか し，ここでは簡単化のため，この影響は考慮しないもの とする. また, これらの交通容量, 交通需要量は, 地震 発生後の各復旧段階で異なるものであり，それぞれの復 旧段階に応じて解析を行う必要があると考える. 以上求 めた地震後の交通容量と交通需要量とから地震後の交通 流を算定する.この際用いるべき交通量の配分方針は平 常時とは異なるものと考えられる．しかし，第 1 近似と しては平常時の交通配分方法を用いてもよいと考える. 得られた交通配分の結果は道路の破壊状況に依存し，こ こでは破壊を確率事象であると考えているため，このシ ミュレーションを多数回繰り返す.

(4) (3)に示したシミュレーションにより求まる地震後 の交通流を統計的に分析し，地震に対する道路交通シス テムの機能上の耐震性の評価を行う。また，システムの 耐震性の観点から各道路の役割を評価する.

\section{（2）地震後における各道路の役割の評価}

（1）で示した方法を本節では簡単な道路交通システム のモデルに適用した. 単純なモデルの例として, 二大都 市（節点(1)，(2)）を幹線道路（リンク(1)-(3)，(3)-(2) およ び一般道路（リンク (1)-(4), (4)-(2) の並列な 2 本の道路 で結んだ道路交通システムを考え（図一4），平常時の OD 分布交通量を表一1 のように仮定した. 各運転者 は最短時間のルートを選ぶものと仮定し，また平常時に は道路の混雑はなく，一定の制限速度 $(40 \mathrm{~km} / \mathrm{h})$ で走 行できるものと仮定し, 各道路に配分される交通量を算 定し, 配分交通量のちょうど 2 倍が道路の容量としてシ ステムが設計されているものと考えると，各道路の容量 は表一2に示すようになる，一方，道路の破 壞箇所は互いに独立なポアソン過程であり, 単位距離当たりの破壊の期待件数をリンク (1)-(3)では 0.3 か所 $/ \mathrm{km}$ と大きく, 他のリン クでは 0.05 か所 $/ \mathrm{km}$ と小さく仮定した.ま た, 破壊の程度 $r$ は

$r=1-$ (地震後の交通容量)/

(平常時の交通容量)

で与えられ，この值を 0 1 の間で一様分布 する独立変数と仮定した. また，各リンクの 交通容量は，そのリンク内の破壊箅所におけ

$$
\nu=0.3
$$

$$
\nu=0.05
$$

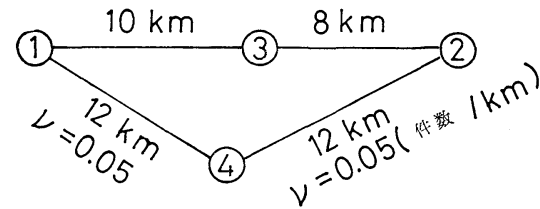

図一4簡単な道路交通システムのモデル
表一1 各節点間の OD 分布 交通量

\begin{tabular}{c|rrrr}
\hline 節点番号 & \multicolumn{1}{|c}{1} & \multicolumn{1}{c}{2} & \multicolumn{1}{c}{3} & \multicolumn{1}{c}{4} \\
\hline 1 & 0 & 560 & 140 & 100 \\
2 & 560 & 0 & 190 & 100 \\
3 & 140 & 190 & 0 & 0 \\
4 & 100 & 100 & 0 & 0 \\
\hline
\end{tabular}

表一2 各リンクの交通 容量 (平常時)

\begin{tabular}{c|c}
\hline リンク & 交通容量 \\
\hline (1)-(3) & 1400 \\
(1)-(4) & 200 \\
(2)-(3) & 1500 \\
(2)-(4) & 200 \\
\hline
\end{tabular}

る容量の最小值に 等しいものと考え た. また混雑度 $K$ （道路の交通容量 に対する断面交通 量の割合）と（走 行速度) $V$ の関係 として図一5を仮 定し,また，各運 転者は地震後にお

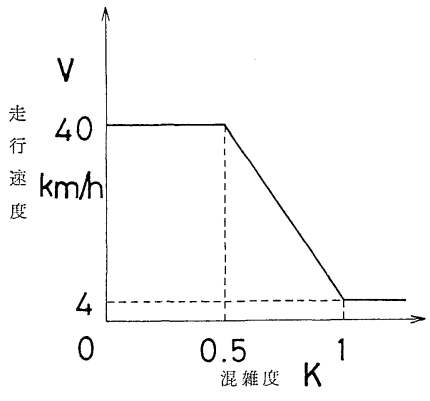

図一5 混雑度と走行速度との関係 いても最短時間のルートを選ぶものと考え，ダイクスト ラ法および分割配分法を用いて交通量配分を行った.

地震後の交通流のシミュレーションを50 回繰り返 し，横軸に混雑度（地震後の交通容量に対する断面交通 量の割合)，縦軸に犠牲度 ${ }^{24}$ （平常時の交通容量に対す る断面交通減少量の割合）を之り，各道路別にまとめた ものが図一6である.システムにまったく破壊が生じて いない平常時には，上記の仮定より混雑度は 0.5 であ り，犠牲度は 0 であることから，各道路の状態は図の中 央に位置している．また，各リンク内の破壞の程度の最 大值 $r_{\max }$, 平常時 および地震後の混雑度 ( $K$ および $\left.K^{\prime}\right)$ ，犠牲度 $G$ の間には次の関係が存在する，つまり，

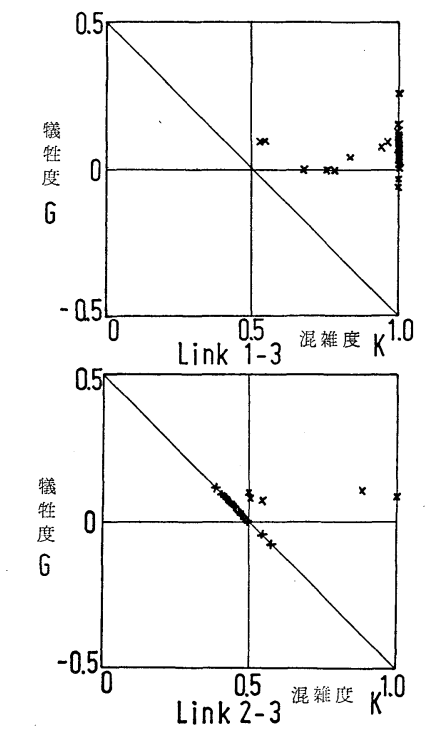

図一6 各リンク別に調べた混雑度と犠牲度との関係
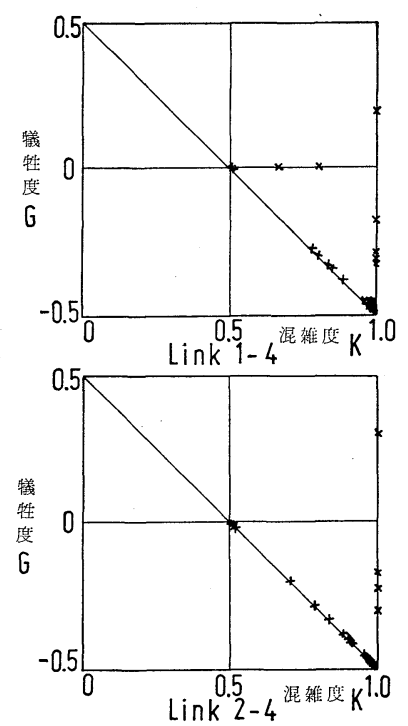
交通容量を地震前後それぞれに対し $Y, Y^{\prime}$ とおき，断 面交通量を同様に $D, D^{\prime}$ とおくと, 犠牲度 $G$ は次式 のように変形される.

$$
\begin{aligned}
G & =\left(D-D^{\prime}\right) / Y \\
& =D / Y-\left(D^{\prime} / Y^{\prime}\right) \times\left\{1-\left(Y-Y^{\prime}\right) / Y\right\}
\end{aligned}
$$

ところが,

平常時の混雑度 $K=D / Y$

地震後の混雑度 $K^{\prime}=D^{\prime} / Y^{\prime}$

破壊程度のリンク内最大值

$$
r_{\max }=\left(Y-Y^{\prime}\right) / Y
$$

を用いると，

$$
G=K-K^{\prime}\left(1-r_{\text {max }}\right)
$$

の関係が得られる. 平常時の混雑度 $K=0.5$ である本 例に対して得られるリンク内の破壊程度の最大值が一定 である線を 図一7 に示してある.

図一6 より各リンクに対する混雑度および犠牲度の值 を比較すると, リンク(1)-(3)では右上に, リンク(2)-(3)で は左上に, リンク (1)-(4)および(2)-(4)では右下に分布して いることがわかり，これらの值はリンクによって大きく 異なることが認められる．また，これらの分布の相違 は次のように説明できる.つまり, 他のリンクと比較し て破壊確率が大きい リンク(1)-(3)では，交通容量が地震 後減少し, 混雑が著しくなり, したがって他のルート 一交通が迁回するために交通量が減少しやすいことにな り, 混雑度は平常時 (0.5) より大きくなり, 犠牲度は正 の值を示す.一方, リンク(2)-(3)では, 直列に連なる他 のリンク (1)-(3)の破壞により他のルートー交通が迁回す るため交通量が減少し, 地震後道路がすきやすくなる. つまり, 混雑度は平常時より小さくなり, 犠牲度は正の 值を示す。また, リンク (1)-(4), (2)-(4)は, 並列なリンク (1)-(3)の破壞により，大都市節点(1)，(2)間の交通が迂回 してくるために破壊しなくても混雑しやすいことがわか る.つまり, 並列な他のリンクの破壊により交通量が増

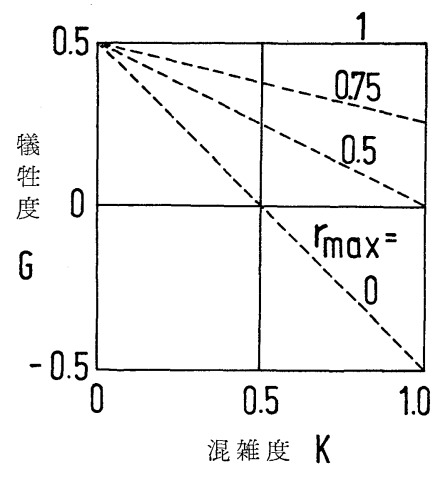

図一7 各リンク内の破壊の程度の 最大值 $\boldsymbol{r}_{\max }$, 混雑度 $\boldsymbol{K}$, および犠牲度 $\boldsymbol{G}$ の関係

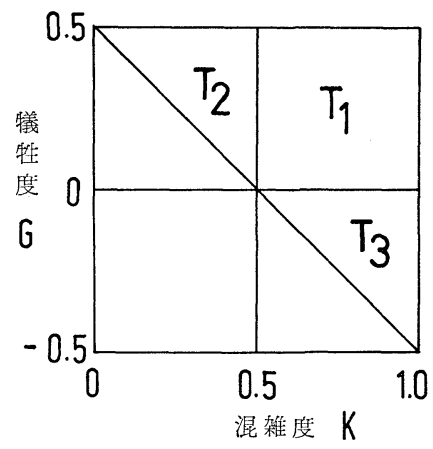

図一8 混雑度-犠牲度, $K-G$ 面の 3 区画への分割

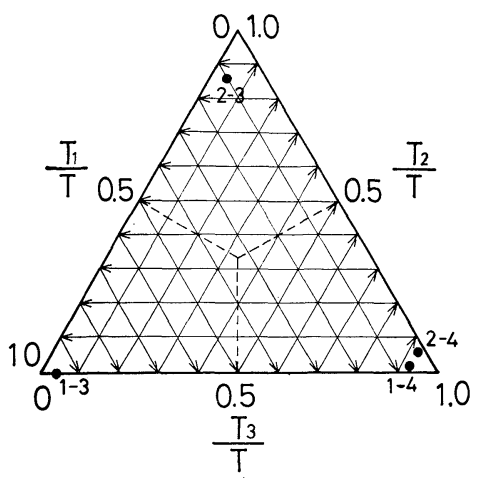

図一9 三角座標を用いた各道路の特性の表示

え（犠牲度 $<0$ ), したがって, 混雑度が平常時より増 加するリンクである.ただし，以上で用いた直列，並列 の考えは，大都市節点(1)，(2)を需給節点と考え，節点(3) および(4)における需要供給量 (発生吸引交通量) は無視 した場合に適用できる考えである。

以上得られた結果を用いて, システムの耐震性の観点 から調べた各道路の役割を明確にするため, 図一8の ように平常時（混雑度 $=0.5$, 犠牲度 $=0$ ）を原点とみな し，3つの区画に分け，各区画内に生じたシミュレーシ ヨンの結果の個数を数え上げた. 右上, 左上, 右下の区 画内のプロット数をそれぞれ $T_{1}, T_{2}, T_{3}$ とおき，シミ ニレーションの全回数に対するそれぞれの值, $T_{1} / T$, $T_{2} / T, T_{3} / T$ を 3 軸とし, 三角座標を構成し, 各道路に ついて示したものが 図一9 である.ただし，

$$
T_{1} / T+T_{2} / T+T_{3} / T=1
$$

であることを利用している．図一9より，リンク(1)-(3) は左下に, リンク (2)-(3)は中央上に, リンク (1)-(4), (2)-(4) は右下に明瞭に分かれて位置している. この図で $T_{2} / T$ の值が大きい，つまり上方ほど，すきやすい道路を示し ており，逆に下方ほど，混雑しやすい道路を示してい る. 一方, $T_{3} / T$ の値が大きい道路（右方）は，他の道 路の破壊により混雑しやすい道路を示し， $T_{1} / T$ の值が 大きい道路（左方）は，その道路自体の 破壊により混雑しやすい道路を示してい る.

\section{6. 数值計算例}

本章では，実際の道路交通システムの 一例として, 図一10 に示した伊豆半島 の道路網を対象とし，道路施設の破壊確 率の推定，連結性を考慮したシステムの 耐震性の評価，交通容量を考慮したシス テムの機能低下の評価を行った. 


\section{（1）連結性を考慮したシステムの耐震性}

まず最初に，震源位置，地盤条件の影響を除いてシス テムの形状の影響のみを考慮して, システムの構造を 4. に示した手法を適用して算定した. ここでは道路 1 $\mathrm{km}$ 当たりの破壊箇所の期待数 $\nu=0.05$ か所 $/ \mathrm{km}$ と仮 定し，式 (1)，（2）を用いて各リンクの非破壊確率 ${ }_{s} q_{i j}$ を算定し, 田村・川上 ${ }^{8), 10)}$ により提案されたモンテカル 口法を用いた方法に従い，すべての節点ペア間の連結確 率 $s p_{i j}$ を算定した (表一3 参照).ただし，本表中の 節点番号, リンク番号は 図一10 に示してあり，また， シミュレーションの回数は 50 回とした. この結果に 4. （2）で示した方法を適用し，システムの構造の視覚化を

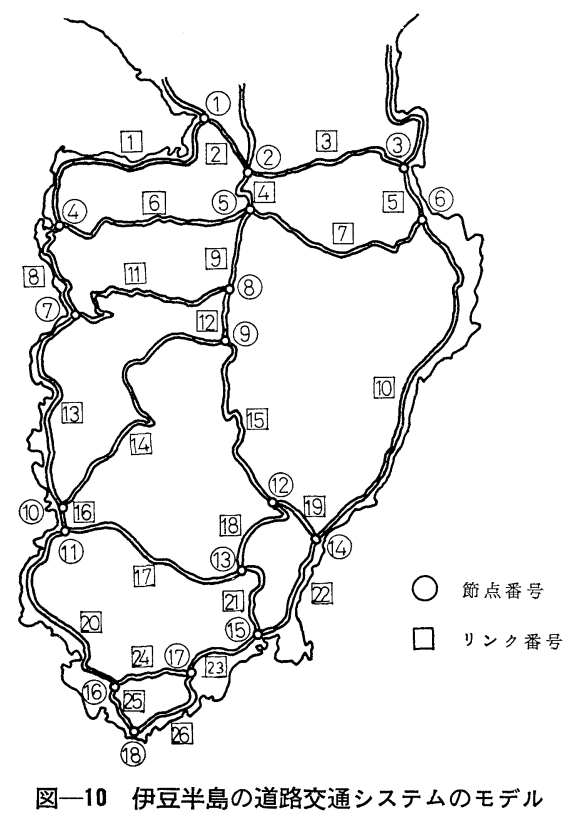

試みた. 図一11 に第 1 , 第 2 主軸を図一12 に第 3 , 第 4 主軸をそれぞれ横軸, 縦軸として, 連結確率から調べ たシステムの構造を示してある. 図一10 のシステムの 地図上の形状と図一11 とを比較すると, 第 1 主軸が南 北に，第 2 主軸が東西に対応し，実際のシステムの形状 が多少変形されて, 図一11 が求められていることがわ かる. つまり, 節点間の地図上の相対距離が大きいほ ど, 非連結確率が大きいように設計された道路網である ことが認められる。

次に, システムの形状の影響に加えて, 震源位置およ び地盤条件の影響をも考虑してシステムの構造を算定し た.ここでは, 各リンクの破壊箇所の期待数を図一1に 示した伊豆大島近海地震 (1978) による各リンクの破壊 箇所数に等しいと仮定した. 前と同様に非破壊確率, 連 結確率を算定し, 図一13 に第 1 , 第 2 主軸を横軸, 縦 軸とした, 連結確率から調べたシステムの構造を示して

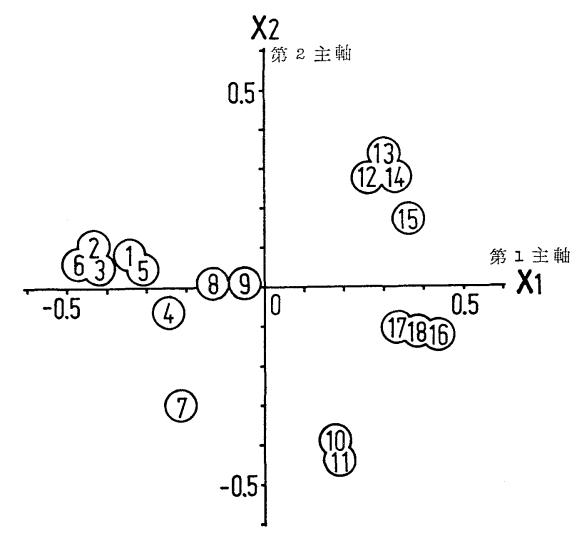

図一11 節点 (1)〜(18) 相互間の非連結確率を距離とした 多次元尺度表示一第 1,2 主軸一（道路 $1 \mathrm{~km}$ 当たりの破壊箇所の期待数 $\nu=0.05$ か所 $/ \mathrm{km}$ )

表一3 節点ペア間の連結 確率

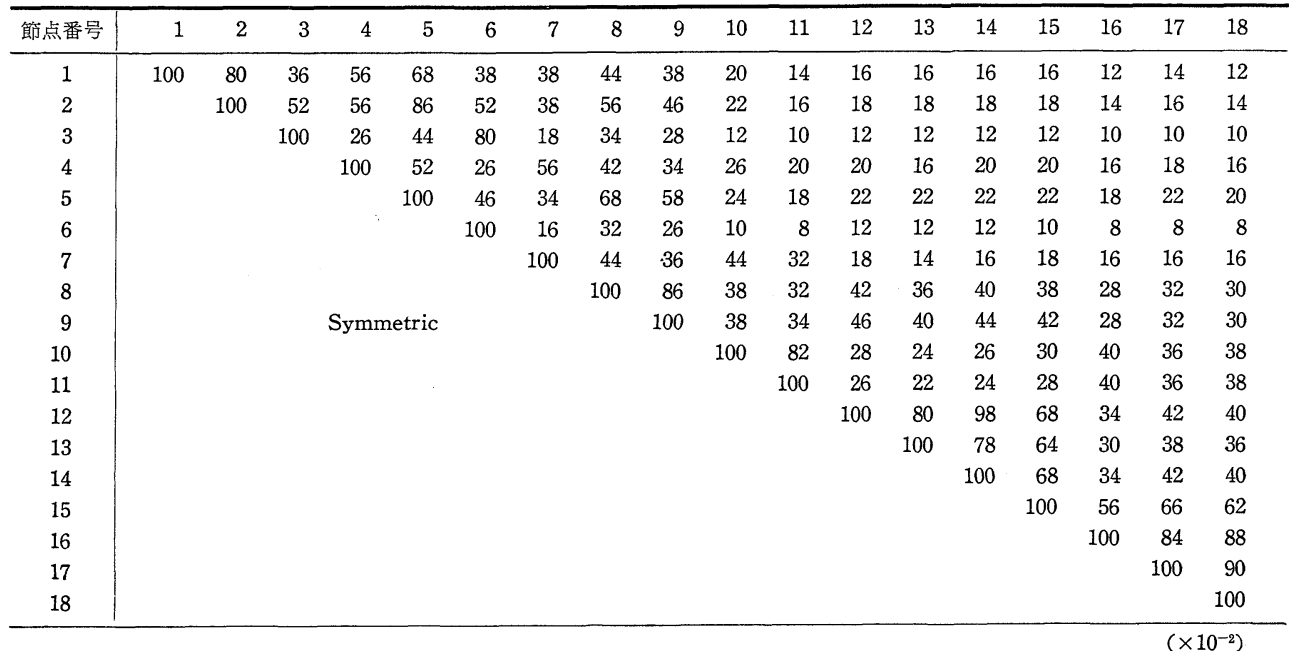




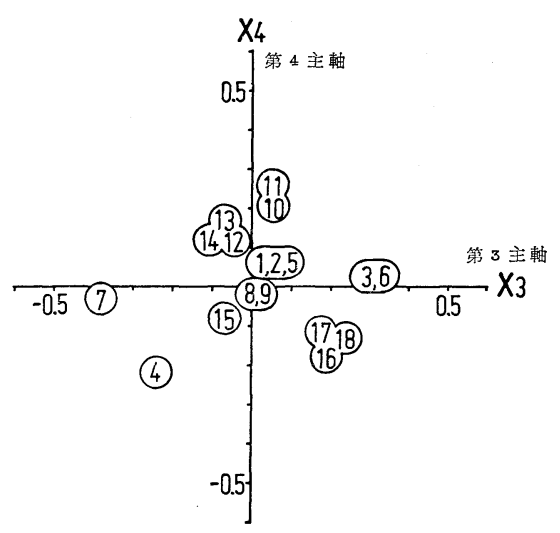

図一12 節点 (1)〜18) 相互間の非連結確率を距離とした多次 元尺度表示一第 3,4 主軸一（道路 $1 \mathrm{~km}$ 当たり の破壊箇所の期待数 $\nu=0.05$ 加所 $/ \mathrm{km}$ )

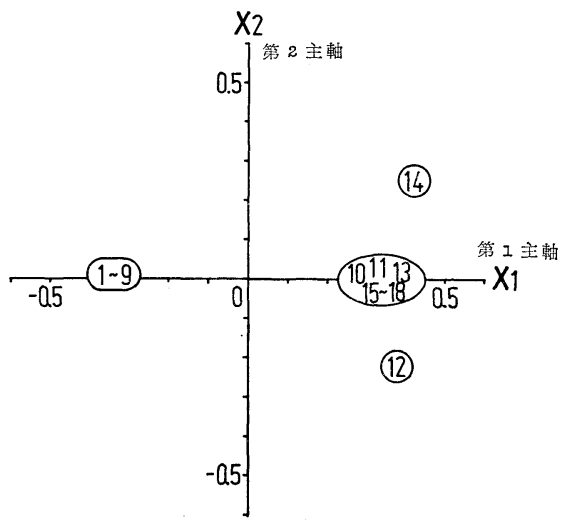

図一13 節点 (1)〜18) 相互間の非連結確率を距離とした 多次元尺度表示一第 1,2 主軸一（各道路の破 壊籄所の期待数 $=$ 伊豆大島近海地震による各 道路の破壊䇢所数)
いる. システムは節点 $1 \sim 9$, 節点 12 , 節点 14 , および その他の節点と 4 つのサブシステムに連結確率の面から みて分けて考えることができることがわかる.このこと は，同様な地震が生じた場合には，震源域内に打ける孤 立地域（節点 12 または 14）のほかに，震源から離れて おり，その地域での被害は少ないのにもかかわらず孤立 してしまう地域（節点 $10,11,13,15 \sim 18$ のグループ） の 2 種類の孤立地域があることを示している.これらの 結果は，地震直後においても，緊急車のための交通路が 確保されるように交通システムの形状および各構造物の 強度を設計するに際して，または，病院・消防署などの 緊急施設が有効に機能するように配置するに際して，利 用できる資料となるものと考えられる.

\section{（2）交通容量を考慮したシステムの機能低下の評価}

次に（1）で用いたものと同じ伊豆半島の道路交通シ ステムに対し，5. で示した方法を適用し，交通容量を も考慮してシステムの機能低下の程度を検討し, さら に，地震後における各道路の役割または特性を，システ ムの耐震性の観点から評価した.

まず，平常時の交通流を以下の手順で算定した.

(1) 各節点を中心とする各ゾーン別人口を参考とし て，各節点の発生・吸引交通量を仮定した.

(2) (1)の結果を用いて，重力モデル式，フレータ法に より, 各節点間の OD 分布交通量を 表一4 のように算 定した.

(3) 5. (2) の単純なモデルの場合と同様に，各運転者 は最短時閒のルートを選ぶものと仮定し，また，平常時 には道路の混雑はなく，一定の制限速度 $(40 \mathrm{~km} / \mathrm{h})$ で 走行できるものと仮定し，各道路に配分される交通量を 算定した.

表一4 各節点間の OD 分布交通量

\begin{tabular}{|c|c|c|c|c|c|c|c|c|c|c|c|c|c|c|c|c|c|c|c|}
\hline 節点番号 & 1 & 2 & 3 & 4 & 5 & 6 & 7 & 8 & 9 & 10 & 11 & 12 & 13 & 14 & 15 & 16 & 17 & 18 & 合 \\
\hline 1 & 0 & 75 & 2 & 5 & 16 & 64 & 6 & 1 & 3 & 2 & 1 & 0 & 2 & 5 & 4 & 0 & 1 & 0 & 187 \\
\hline 2 & & 0 & 6 & 8 & 102 & 208 & 10 & 6 & 9 & 5 & 3 & 2 & 5 & 11 & 10 & 2 & 2 & 2 & 466 \\
\hline 3 & & & 0 & 1 & 3 & 303 & 1 & 1 & 1 & 1 & 1 & 0 & 1 & 2 & 2 & 1 & 1 & 0 & 327 \\
\hline 4 & & & & 0 & 6 & 34 & 17 & 2 & 3 & 4 & 2 & 0 & 2 & 5 & 2 & 0 & 0 & 0 & 91 \\
\hline 5 & & & & & 0 & 167 & 8 & 9 & 11 & 5 & 3 & 2 & 3 & 11 & 7 & 1 & 1 & 0 & 355 \\
\hline 6 & & & & & & 0 & 56 & 16 & 30 & 30 & 17 & 6 & 22 & 93 & 74 & 12 & 9 & 5 & 1146 \\
\hline 7 & & & & & & & 0 & 2 & 5 & 13 & 8 & 1 & 4 & 9 & 9 & 3 & 2 & 0 & 154 \\
\hline 8 & & & & & & & & 0 & 6 & 1 & 1 & 0 & 1 & 3 & 1 & 0 & 0 & 0 & 50 \\
\hline 9 & & & & Symn & etric & & & & 0 & 3 & 2 & 1 & 2 & 9 & 5 & 0 & 1 & 0 & 91 \\
\hline 10 & & & & & & & & & & 0 & 106 & 1 & 5 & 8 & 11 & 6 & 2 & 2 & 205 \\
\hline 11 & & & & & & & & & & & 0 & 1 & 5 & 6 & 9 & 5 & 2 & 1 & 173 \\
\hline 12 & & & & & & & & & & & & 0 & 4 & 55 & 5 & 1 & 1 & 0 & 80 \\
\hline 13 & & & & & & & & & & & & & 0 & 30 & 68 & 3 & 4 & 2 & 163 \\
\hline 14 & & & & & & & & & & & & & & 0 & 94 & 8 & 8 & 2 & 359 \\
\hline 15 & & & & & & & & & & & & & & & 0 & 18 & 31 & 7 & 357 \\
\hline 16 & & & & & & & & & & & & & & & & 0 & 13 & 9 & 82 \\
\hline 17 & & & & & & & & & & & & & & & & & 0 & 4 & 82 \\
\hline \multirow[t]{2}{*}{18} & & & & & & & & & & & & & & & & & & 0 & 34 \\
\hline & & & & & & & & & & & & & & & & & & & 4402 \\
\hline
\end{tabular}


(4) (3)で得られた平常時の配分交通量のちょうど2 倍 の量が道路の容量としてシステムが設計されているもの と仮定した.

一方，道路施設の破壞については，3．で概説したよ うな手順で推定することが可能である． seismicity，地 盤条件, 構造物の強度などを考慮して破壊箇所を推定す る必要がある．たとえば斜面崩壊という破壊モードに対 しては，各道路に沿う斜面の状況と震度分布から破壞確 率を推定することが可能であり, 他の破壞モードに対し ても同様に破壞確率を推定する必要がある.これら破壞 確率の推定值はシステムの安全性を評価する際に最む基 本的な役割を果たすものであり, 解析結果の信頼性を高 めるためにはこの推定の精度を向上させることが必須で ある. 実際の道路網の解析に際しては, 最も精度のよい 詳細なデータを使用し, 考え得る限りの多くの要因を考 慮に加えた解析が必要である. しかし，一方，基礎的な 研究に際しては, いたずらに解析を複雑にすると, 計算 時間・容量のらえから問題となるばかりでなく, 各要因と 結果との対応を把握しにくくなる. 本節では, まず, 道 路網が不規則な形状をしていることによる影響のみを考 え, 各道路の破壊確率がその長さのみによって決まる場 合を考えた. そして，ここでは，一例として，各道路の 破壊に関して次の簡単な仮定を設定した.

(1) 道路の破壊箇所は互いに独立なポアソン過程であ り, 道路の単位距離当たりの破壞の期待件数を一定值 0.2 か所 $/ \mathrm{km}$ であると仮定した.

(2) 単純なモデルの場合 (5. (2)) とまったく同様に, 破壊の程度を式 (14) のように, 交通容量の減少量と関 連付け, この值 $r$ を 1 の間で一様分布する独立変数 であると仮定した.

さらに，地震後の交通流のシミュレーションを行うに 際し，ここでは次のような仮定を行った.

(1) 各リンクの交通容量は, そのリンク内の破壊籄所 における容量の最小值に等しい。

(2) 混雑度と走行速度との間に図一5 の関係が成り立 つ.

(3) 各運転者は最短時間のルートを選ぶものとする.

(4) 地震後の $\mathrm{OD}$ 分布交通量は平常時のものと等し W.

地震後に拈ける交通需要量は, 前述したように, 平常 時とは大きく異なるものと考えられる. 地震が及ぼす社 会的・経済的影響により，また各トリップの目的によ り,さらにはこれから求めようとしている地震後の交通 流の状態により，また地震発生後の各復旧段階で大きく 異なるものと考えられる. しかし，ここでは簡単のため 一例として, 地震後の $\mathrm{OD}$ 分布交通量が平常時のもの と等しいと仮定して計算を行った. 今後, 地震後の交

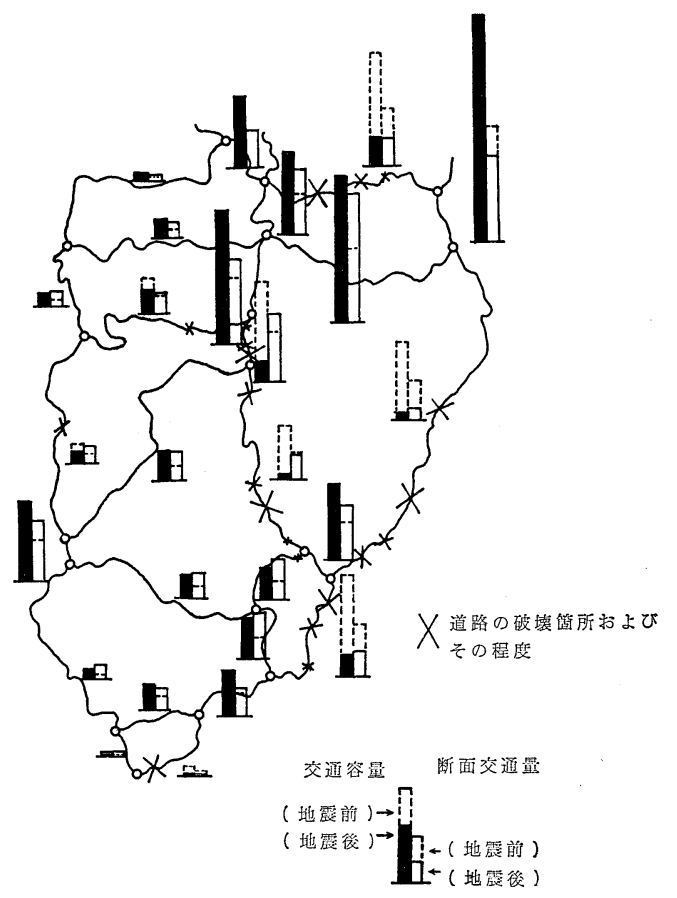

図一14 シミュレーション結果の一例

通需要の予測に関する問題は重要な問題となると考えら れる. その際, 伊豆半島地域の交通の特徵である観光交 通量をも十分に考慮して解析を行う必要があると考え る.

得られたシミュレーションの結果の一例を 図一14 に 示す. ×印は道路の破壊の位置と程度とを示し, また, 各道路に対し，交通容量および断面交通量をそれぞれ左 右の棒グラフで示し, さらに, 各棒グラフに対して, 地 震前と地震後の交通量がそれぞれ破壞および実線で示し てある. 仮定により, 地震前の断面交通量は, 地震前の 交通容量のちょうど半分に定めてある.

同様のシミュレーションを 50 回繰り返し, 横軸に混 雑度, 縦軸に犠牲度をとり, 各道路別にこれらの值をプ ロットした. この一例としてリンク 10，26，16，19 に 対する図を図一15 に示す. さらに，5.(2) に示した手 法に従い三角座標を用いて各リンクの特性を表わしたも のを 図一16 に示す.この図より, リンクは特性の面か らみて, リンク 10 , リンク 26 , リンク 16 を一例とす るグループ, リンク 19 を一例とするグループの 4 つの グループに大別されることがわかり，5. (2) の簡単なモ デルの場合と同様に, 各道路の特徵をシステムの耐震性 の観点から検討することが可能である. つまり，リンク 10 は長いリンクであるため破壤する確率が大きく，そ のリンク自身の破壊により混雑しやすいリンクである. 一方, リンク 26 は他のリンクの破壊の影響を受け交通 量が減少し, 混雑しないリンクである. また, リンク 16 

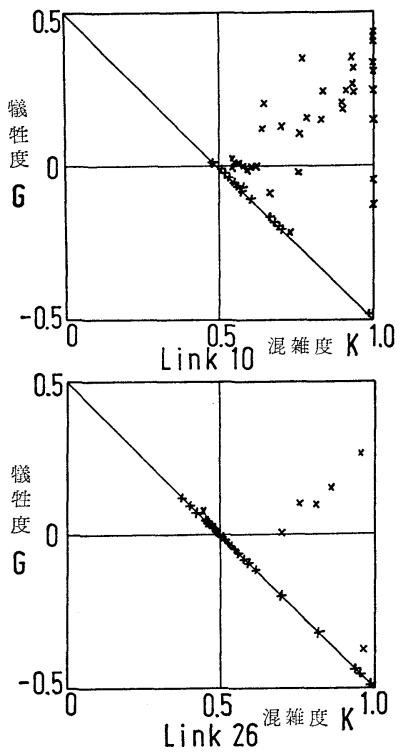
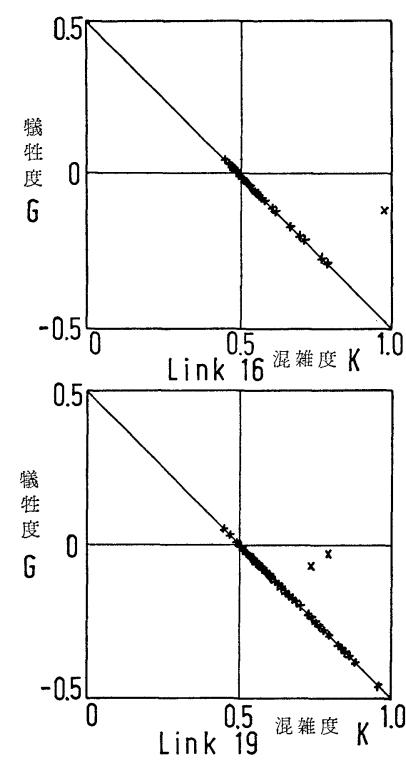

7. 結

本研究は地震に対する道路交通システムの 機能上の安全性を評価するための方法を確立 し,さらには，地震後のシステムの状態をそ の機能面から検討し, 地震後のシステムの状 態，およびシステムを構成する各道路のシス テム内における役割を明らかに評価するため の方法を確立する目的で実施されたものであ

図一15 各リンク別に調べた混雑度と犠牲度との関係

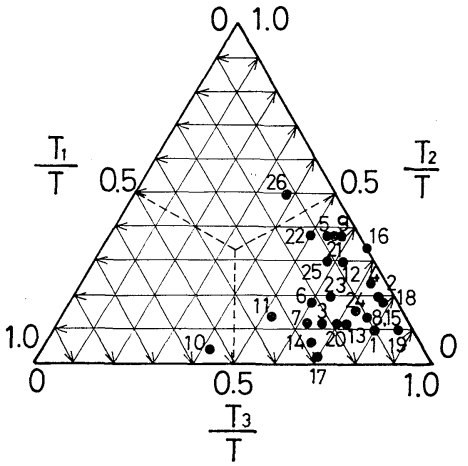

図一16 三角座標を用いた各道路の特性の表示

を一例とするグループは, 他のリンクが破壊することに 影響されて混雑する場合がやや多いリンクであり，リン ク 19 を一例とするグループは, 他のリンクの破壞によ り混雑する場合が多いリンクである.

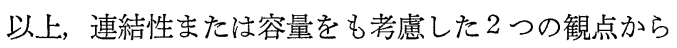
道路交通システムの耐震性の評価方法を展開し, また, 地震後のシステムの状態および各道路のシステム内にお ける役割を分類, 評価するための方法を提案し, その適 用例を示した.

もとより, 地震後のライフラインシステムの機能低下 の状態を震害調査の一環として実際に調査するようにな ってきたのはこの数年であり, 伊豆大島近海地震の際に も地震後の交通量の測定は行われていない. また, 数值 シミュレーション結果においても多くの仮定を設定する ため, 得られた結果が地震後の状態を正確に表わしてい るものではない. 本方法は今後さらに改良発展させ, 地
る.

（1）第 1 に，過去の地震による道路施設の破壊状況 の一例として, 伊豆大島近海地震 (1978) によるものを 概説した. これらの多くの震害記録に基づいて，道路交 通システムの機能低下の原因を列挙し, この大部分の原 因である各道路施設の破壞に関する従来の多くの研究の 一例として, ここでは斜面崩壊の発生に対する解析手段 および得られている結果について概説した. そして, こ れらの研究成果を反映してシステムの機能上の耐震性を 評価するための確率論的なモデルを組み立てることが可 能であることを示した. 本研究はこれらの従来の研究成 果に対する新しい利用方法を提示したものであり，今 後, この新しい利用方法を考慮したこれらの研究のさら なる進展が望まれる.

（2）第 2 に, 地震直後において, 交通途絶地域（孤 立地域）が生じることは緊急車の活動の妨げとなり，二 次災害を大きくさせる原因となると考え, 各地域閒の連 結性に着目し, 地震後のシステムの状態を検討するため の方法を展開した. ただし，連結性を表わす指標として は,すべての節点ペア間の連結確率をモンテカルロ法に より算定したものを用いた. 次に, 非連結確率が距離と しての性質を満足することを明らかにすることにより， 多次元尺度構成法を用いて，連結性の観点からシステム をいくつかのサブシステムに分割することを試みた.さ らに, この方法を伊豆半島の道路網に適用した結果, 本 道路網は破壊がシステム全体に一様に生じた場合には, 節点ペア間の地図上の距離が大きいほど, 非連結確率が 大きくなるような形状を有する道路網であり, 孤立地域 が発生しやすいようには設計計画されていないにもかか 
わらず，伊豆大島近海地震のような断層が生じた場合に は, 2 種類の孤立地域が発生する, つまり, 道路施設に 多くの被害が生じる震源域内の孤立地域, および, 震源 から遠く道路施設の被害は少ないにもかかわらず孤立し てしまう地域があることが認められた. これらの結果 は, 対象とする大規模地震に対して, 地震直後において も緊急車のための交通路が確保されるように交通システ 厶の形状を決定し, また, 各構造物の強度を決定するに 際して, または, 病院・消防署などの緊急施設が有効に 機能するように配置するに際して利用できる資料となり 得るものと考えられる.

（3）第 3 に，システムの破壊が地震後長期間にわた って日常生活・産業活動に与える影響を考えた場合, シ ステムの復旧期間中の機能低下の状態を交通容量をも考 慮して予測しておく必要がある. また，さらには，シス テムの機能の耐震性の観点から 各道路の役割を明確に し,この結果を各道路の耐震設計強度の程度に反映させ ておくことが望ましいと考えた．まず，容量をも考慮し た道路交通システムの地震後の機能低下の評価方法を展 開した. これは, 平常時の交通流を基本として地震後の 交通容量を各道路施設の破壊を考慮して推定し, 一方, 地震後の交通需要量を推定し, この両者を用いて地震後 の交通量配分を行う方法である. そして，このシミュレ ーションを多数回繰り返すことにより，道路交通システ ムの耐震性を評価する方法である. さらに, 得られた結 果を各道路の耐震設計強度の程度に反映させるため, 各 道路の地震後の役割を混雑度, 犠牲度の 2 つの指標を用 いて評価する方法を提案した. さらに，三角座標を用い て各道路の特性を表わすことを試みた結果，すべての道 路は，地震後のシステム内における役割の面から， (1) その道路自身の破壊により混雑する道路, (2) 他の道路 の破壞によりすきやすい道路, (3) 他の道路の破壊によ り混雑しやすい道路の 3 種類に大別できることがわか り，また，これらの結果は直列，並列の考えを用いて説 明することが可能であることがわかった. さらに，この 方法を伊豆半島の道路交通網に適用した結果, 同様の分 類が可能であることが示された.

以上, 道路交通システムの耐震性の評価方法を展開 し, また, 地震後のシステムの状態, つまり各道路のシ ステム内における地震後の位置つけまたは役割を検討す るための方法を提案した. さらに検討すべき点む多く残 されているが，本方法は道路交通システムの耐震設計法 を改善していくうえでの新しい有用な情報を提供し得る ものと考える.

謝辞：本論文中の 4. に関しては，著者が東京大 学生産技術研究所第 1 部, 田村重四郎教授の指導のもと
に行った内容である. また， 5. に関しては筑波大学社 会工学系の石田東生氏に助言をいただいた. 本研究中の 数值計算に関しては埼玉大学建設基礎工学科の卒業論文 生であった石井良雄君（現・パシフィックコンサルタン ツ）に，また，図面の作成にあたっては埼玉大学文部技 官の堀野浩美君にご協力をいただいた. 未筆ながら深謝 の意を表します.

\section{参考 文 献}

1) 岡本舜三 : 耐震工学, オーム社, 1971 .

2）八十島義之助・花岡利幸 : 交通計画, 技報堂, 1971 .

3）佐々木 網 : 都市交通計画, 国民科学社, 1974 .

4) Panoussis, G. : Seismic reliability of lifeline networks, Seismic Design Decision Analysis-Report No. 15, MIT, Dept. of Civil Eng. Res. Rep. R 74-57, 1974.

5) Taleb-Agha, G. : Seismic risk analysis of networks, Seismic Design Decision Analysis-Report No. 22, MIT, Dept. of Civil Eng. Res. Rep. R 75-49, 1975.

6) Shinozuka, M., S. Takada and H. Kawakami : Risk analysis of underground lifeline network systems, USSouth East Asia Symposium on Engineering for Natural Hazards Protection, Manilla, Philippines, Sept. 1977.

7) Shibata, H. and M. Tsuchiya : Fundamental concept of aseismic design of earthquake resistant lifeline systems and industrial facilities, The Current State of Knowledge of Lifeline Earthquake Engineering, ASCE, 1977.

8）田村重四郎・川上英二：ライフラインのネットワークシ ステムの耐震性の一評価方法について, 生産研究, 30 巻 7 号, 1978.

9）伯野元彦・斉藤嘉則 : ライフ・ラインの而震性に影響す る因子, 第 15 回地震工学研究発表会講演概要, 1979.

10）田村重四郎・川上英二：モンテカルロ法による地中埋設 管システムの耐震性の評価方法, 土木学会論文報告集, 第 311 号, 1981 .

11) Isoyama, R. and T. Katayama : Practical performance evaluation of water supply networks during seismic disaster, ASCE Specialty Conference on Lifeline Earthquake Engineering, 1981.

12）星谷 勝・小池精一：ライフラインの地震災害における 復旧予測モデル，土木学会論文集，第 308 号，1981.

13）篠塚正宣・小池 武：埋設ライフラインシステムの連結 性能に関する地震危険度解析, 第 311 号, 1981 .

14）川上英二 : 少数種類の 構造物からなるライフラインシス テムの耐震性の評価, 土木学会論文集, 第 312 号, 1981 .

15) Britz, K., P. Edelstein and I. Oppenheim : Measurement of earthquake performance of transportation systems, The Current State of Knowledge of Lifeline Earthquake Engineering, ASCE, 1977.

16) Longinow, A., E. Bergmann and J. Cooper : Bridge retrofitting selection of critical bridges in a road network, The Current State of Knowledge of Lifeline Earthquake Engineering, ASCE, 1977.

17）高橋邦雄・堀井雅史・福田 正：災害時における道路網 の交通流予測，第 16 回自然㷋害科学総合シンポジウム， 1979.

18）恒石幸正・伊藤谷生・狩野謙一：岩盤強度よりみた伊豆 大島近海地震の道路災害, 第 15 回自然災害科学総合シン ポジウム, 1978 .

19）岩崎敏男・川島一彦・森本 䉰 : 斜面の 地震応答特性の 
一解析, 第 35 回土木学会年次学術講演会講演概要集, 第 I 部, 1980 .

20）田村俊和：地震により表層滑落型崩壤が 発生する範囲に ついて, 地理学評論, 51-8, 1978.

21）国井隆弘・望月利男・松田磐余・田村俊和：1978 年伊豆 大島近海地震の地震断層と各種被害の分布, 第 15 回自然 災害科学総合シンポジウム, 1978.

22）荏本孝久・国井隆弘：1978 年伊豆大島近海地震における
道路斜面の被害分布と被害発生要因の解析, 第 35 回土木 学会年次学術講演会講演概要集, 第 I 部, 1980 .

23) Torgerson, W.S.: Theory and Method of Scaling, John Wiley, 1958.

24）建設省士木研究所・長大橋設計 センター：交通量推計に 関する調查解析, 1978 . 